\title{
Art therapy as counseling modality to help delinquent students
}

\author{
Wan Muhammad Baihaqi Wan Hamat ${ }^{1}$, Abu Yazid Abu Bakar ${ }^{2 *}$ \\ ${ }^{12}$ Universiti Kebangsaan Malaysia
}

\begin{tabular}{|c|c|}
\hline Article Info & ABSTRACT \\
\hline Article history: & The purpose of this psycho-educational group counseling is to provide \\
\hline $\begin{array}{l}\text { Received Dec } 12^{\text {th }}, 2020 \\
\text { Revised Jan } 20^{\text {th }}, 2020 \\
\text { Accepted Feb } 16^{\text {th }}, 2020\end{array}$ & $\begin{array}{l}\text { knowledge and information to target groups on their delinquent problems. } \\
\text { Delinquent is an attitude that violates the law that society does not accept but } \\
\text { not serious. Delinquent problems are often associated with adolescents either } \\
\text { in primary school or high school. The participants were } 26 \text { students from one } \\
\text { of the private schools in Selangor which are from form two and three. The }\end{array}$ \\
\hline Keyword: & $\begin{array}{l}\text { process of selecting participants is through discussions with the school } \\
\text { counselor, and the participants are those who have identified disciplinary }\end{array}$ \\
\hline $\begin{array}{l}\text { Art Therapy, Delinquent, Group } \\
\text { Counseling, Psycho-education }\end{array}$ & $\begin{array}{l}\text { records involved in delinquency issues. The researchers conducted four group } \\
\text { counseling sessions. Participants were divided into three groups according to } \\
\text { their disciplinary problems. The module used in this program is art therapy } \\
\text { through "LEPAS" approach or known as Luah Emosi Positifkan Akal Sihat. } \\
\text { The participants aware of their emotions and realize that what are they doing } \\
\text { (disciplinary issues) is wrong and should be stopped as the results of the } \\
\text { involvements in this psycho-educational program. The implications of this } \\
\text { program are directed to the counseling practitioners whose can use the art } \\
\text { approach in dealing with school discipline cases. }\end{array}$ \\
\hline
\end{tabular}

(C) 2020 The Authors. Published by IICET.

This is an open access article under the CC BY-NC-SA license

(https://creativecommons.org/licenses/by-nc-sa/4.0

\section{Corresponding Author:}

Abu Yazid Abu Bakar

Universiti Kebangsaan Malaysia

*Corresponding author, e-mail: yazid3338@ukm.edu.my

\section{Introduction}

The problem of delinquency in schools is an ongoing issue despite various efforts made by various parties. The same things happened in religious schools including a private school located in Selangor. The study of Zulkifli and Azrinawati (2006) shows that some cases of adolescent misconduct in religious schools frighten the community. The problem of delinquency is always changing in the way of an action makes the higher the degree of seriousness and the broader the type and technique to carry out (Ismail, 2000). The service will provide awareness and skills for students with behavioral or disciplinary problems through this execution of psycho-educational activities. The activities that have been carried out in groups are expected to help students improve themselves, thus avoiding problems.

The groups of psycho-educational program were conducted from form two and three of selected students. The program focuses on the psycho-educational group counseling approach. Psycho-education is aimed at providing social skills to group members, and in the context of the program consists of early adolescent students. The program is also intended to provide skills in dealing with problems that have been encountered by students. In addition, this program is essential to assist the recovery and treatment process for students 
depending on the severity of the problem. This program focuses on delinquent issues with some common issues and cases among students such as smoking, vaping, bullying and class skipping. This attitude problems involve the disciplinary of students that should be exterminated by teachers and schools administration.

The objective of the investigation and research is to know about effect in the using of art therapy activities for delinquent student. This research also want to identify the abilities of students who not aware. Thirdly, we want to stabilize their behavior with increase an awareness of delinquent risk for their future especially in studies. This research is an important work for me and the students. It is because may help to record and investigate about delinquent among students. When we know about it, we can look for long time prevention and recovery approaches which appropriate for them.

Some characteristics of delinquent adolescents are long-term, non-cooperative, rebellious, and hostile behaviors that show hostility to those who have authority over them, but do not engage in severe anti-social behavior. (Turgay, 2009). Sontrock (2003), on the other hand, adds that self-control plays an important role in increasing adolescent delinquency. In addition, delinquency issues have many factors such as peer pressure, desire to try and neglection from parents. A working parents nowadays causes children not enough attention and look for other sources to express themselves. This is supported by Hirschi's (1969) statement that social bonding theory also suggests that the negative relationship between parents and children a major factor in delinquent adolescent behavior.

Spiritual aspects also makes an important factors in delinquent issues such as lack of appreciations and morals. Hanafi and Ismai (2006) stated that the absence of appreciation of moral values in society leads to negative behavior and is likely to result in moral collapse resulting from poor moral values. Elfida (2005), on the other hand, explains that the mischief child whose behavior deviates from social, moral and religion norms.

The question of whether this delinquency has the tendency to both genders or only men is proven oby the Jabatan Kebajikan Masyarakat (JKM) report which clearly shows that delinquency is a male phenomena. For example, the 2009 to 2013 reported that 25,778 delinquent cases of 23,950 involve the boys teenager and only 1,828 cases involving teen girls. Lately this cases involving teenage girls have begun to rise. The increase was 135 percent for years 2003 to 2006 and 2009 to 2013. However, the main issue is not the issue of gender, but the potential of such cases to be exterminated. According to the study, among the factors involved in delinquency problems are family aspects such as poor family relationships, family conflicts, socio-economics status and experience of abuses (De La Rue \& Esspelage, 2014).

After this program was run as well, some of objectives or questions answered like effect of art therapy for the students directly after they do the activities every session. We can see the changes through their behavior and verbally. But for a long time, monitoring and further study are needed. Through this psycho education program, we prove that delinquent behavior can be prevented with different method where it is suitable for them include emotion, cognitive and behavior.

Therefore, delinquency is a problem that must be wiped out seriously even it is not simple. This problems are not on teacher's responsibility or a counselor only. More activities should be conducted among teenagers especially school students to provide useful inputs for those who have involved in these unhealthy activities as well as an early prevention. This small-scale issues should be concerned before then become the bigger issues that maybe affect their education and attitude.

\section{Method}

In the social and behavioral sciences, it is important to al ways provide sufficient information to allow other researchers to adopt or replicate your methodology. This information is particularly important when a new method has been developed or an innovative use of an exisiting method is utilized. Last but not least, please avoid making a sub section in Material and Methods.

A planned psycho-educational group counseling program was conducted at one of the private high schools in the State of Selangor. The members of the group were 26 people and consisted of students in form two and three. The process of selecting a group member is through discussions with school counseling teachers for those involve in school discipline cases. As a result, the group members were divided into three groups according to their disciplinary problems. The first group are involved in vape and cigarette problems. The second group involved in bullying and third group are female students who violated school rules such as 
fighting teachers, not doing homework and sleeping in class. Counseling sessions were conducted for four sessions.

To implement the psycho-educational group counseling program, an art therapy approach through the LEPAS approach was used. LEPAS is an acronym for "Luah Emosi [psitifkan Akal Sihat." It contains four main activities namely "roda emosi, persona diri, potret diri and heart vision.". Each of these activities was included in each psycho-educational group counseling session. The first session of the roda emosi module was conducted with the aim of exploring each member's emotions. The second session of the persona kendiri module was conducted with the aim for members to identify themselves from the views of their peers. In the third session, the potret diri module was used.

The methodology will be used are suitable for secondary school and university student. If it wants to apply for other sample like adult person, modifications are needed for this module. The purpose of this module is to see how well the members feel confident with themselves. Members are required to list as many positive things or personal advantages as possible. While in the last session, heart vision activity was used as a closing activity. This activity requires that each member write down their feelings or give motivational words to their peers in the group. Each activity will be followed by a discussion session with the members. The aims are to encourage members to communicate with each other and to build trust between them. At the end of each session, the trainee counselor formulated a discussion that took place within the group.

\section{Results and Discussions}

The first session used the roda emosi module. The purpose of this module is to identify type of emotions they are experiencing today. Some of the members' work during the first session is as shown in Figure 1.

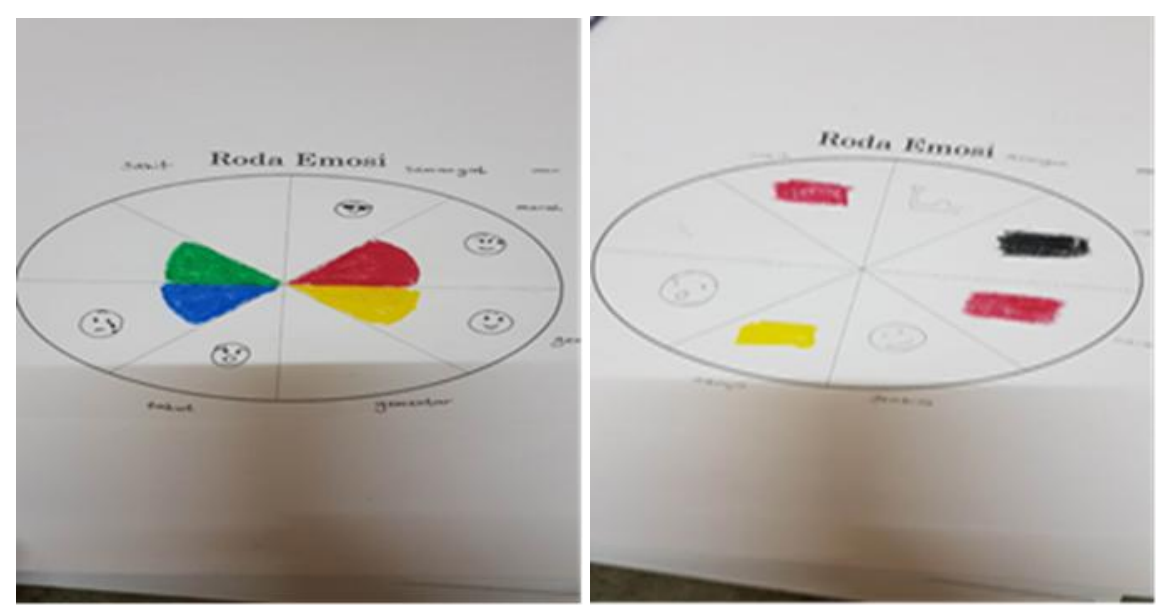

Figure 1.

Figure 1 shows some of the drawings made by members of the group in the first session. Based on these images, it is possible for the student to understand the emotions they are experiencing. However, in the early stages all members of the group found it difficult to understand and describe what was required in this activity. This is because they have no experience in performing art therapy and they never express their feelings and emotions in a visual way, instead of describing them through words alone. To solve the problem, the trainee counselor made a demo drawing for all the members, and finally they understood the module's requirements. The results shown in Figure 1 are an outcomes creativity in expressing their feelings in the first session today.

The second session went well. All members are asked to give their opinions to their friends. At the same time, members have to write their views on themselves. The module used in the second session is persona diri. Two attachments are given to each member. Each member is asked to remove the name of one of their friends, and then write down the advantages or disadvantages of that friend. Figure 2 shows the work done by the members in the group. 


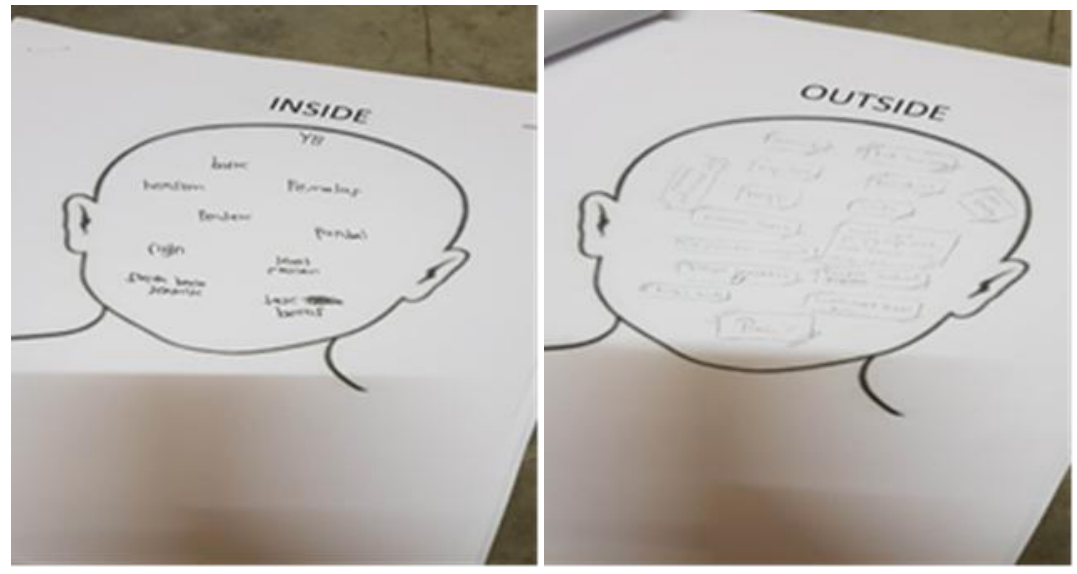

Figure 2.

Figure 2 shows the work done by the group members in the second session. All members of the group were found to be very positive in receiving praise or reprimandings from their peers. This may be due to the close relationship between them. However, an unexpected situation occurred when all members of the group expressed sadness and frustration to one of the group's friends as their relationship making a gap since entering form three. All this time they did not know how to express their feelings, but after engaging in this personal activity, they triggered other members to express themselves. It can be solved when the partners involved are telling the truth and apologizing to the other partner. This situation shows that in the second session the group members began to understand how to express their emotions through drawing and solving them in a wise way.

The activity carried out in the third session is the 'potret diri' module. It is an activity that requires experts to write and list the benefits they have. It aims to encourage members to aware of their potential and to appreciate what they have. Examples of work done by members are in Figure 3.

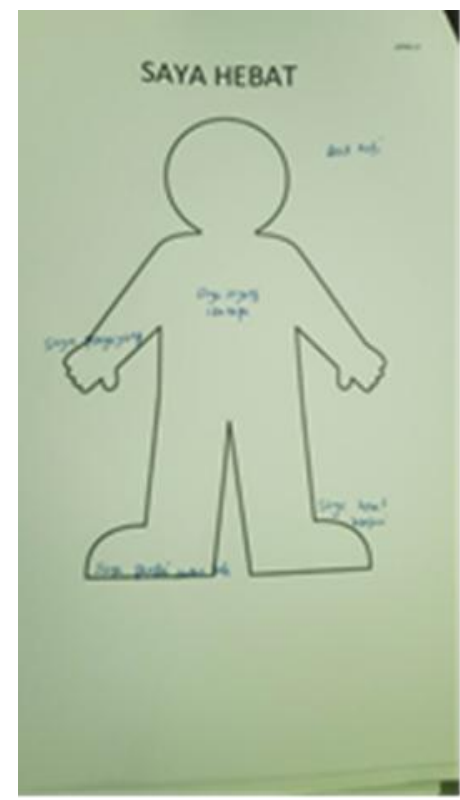

Figure 3 .

The image is the result of a presentation by one of the participants. At this stage, members find it easy to express what they think about themselves. This is because they are aware of the strengths and advantages they have gained through their first and second sessions. 
The activity in the fourth session and closing was using the 'heart vision' module. This activity require members to draw their hands (left and right) on a piece of paper provided by the facilitator. Then, each member of the group will write a comment or say positive words to their friend in the hand drawn drawing. Examples of work are as shown in Figure 4.

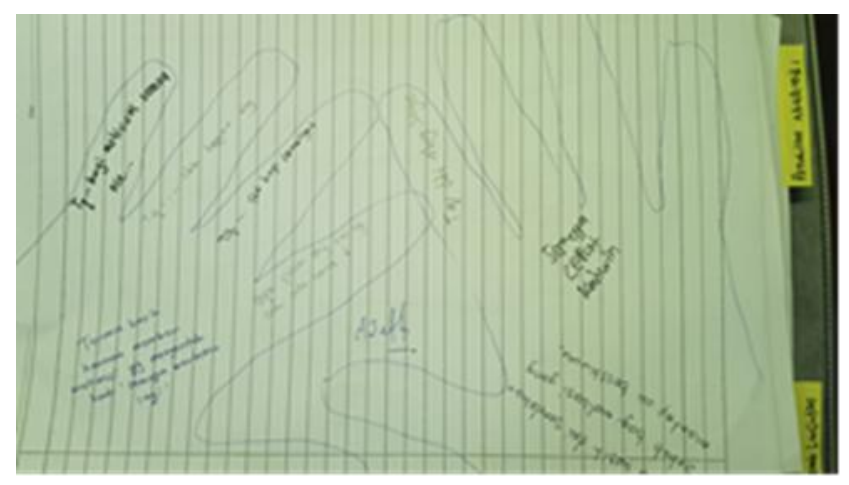

Figure 4. Examples of work

Figure 4 is an example of a member's work. In the palm of the hand, all the members have write in or give a positive comments to their friends. The purpose of this activity is to ishow their appreciation for their friends. This activity is seen as very positive as members enjoy reading comments and words from their friends.

Psycho-educational group counseling had a different impact and experience in each session. The first session shows that the emotions are present in each person varying despite the fact that they are not exposed to facial expressions. The emotions that come out in the activities carried out have meaning and need to be resolved to make their lives more prosperous. This is supported by the study of Nasir and Omar (2006) that prosperous individuals are those who have positive emotions, do not have negative emotions and are satisfied with life. These activities provided an opportunity for members to express and share their own inner feelings. The findings of this study are reinforced by the study of Jamaludin, Ku Johari and Amat (2018) that adapting techniques and strategies to client of psychology is crucial to ensuring goals and objectives in counseling sessions are achieved.

Openness to receive opinions as well as lack of self-esteem are in the second session. Most members of the group have similar concerns and get to know each other. The common of these issues is related to discipline and personal issues. Because members know each other, it makes them aware of each other's attitudes and social ease. According to Sweeney (2009) states that a person of social interest is a person with characteristics of good mental healthiness.

Self-reinforcement can be enhanced and strengthened in the third session. Knowing and seeing the flaws in yourself has made members think about the actions and abilities that will be developed to make themselves better. The actions taken will enable to work on improving their potential while also improving their own wellbeing. Jamaludin, Ku Johari and Amat (2018) said that counselors should use creative interventions to help childrens whose neglected to improve holistic self-care. Self-change requires action from the members themselves because motivation and self-reliance depend on the effort that is going to take. This change includes emotional, cognitive and behavioral.

Therefore, the strength that has been accumulated to change themselves needs to be rewarded and appreciated because strong self-esteem is difficult to discard or alter. It can be seen that in the fourth session, each member will be given the opportunity to give credit to the other members of the group. Support from close friends, especially family members, is an extremely positive reward in improving one's progress. Parents is an important component as it has a significant impact on a child's lifestyle, information on children's developmental history, interaction patterns and parenting. (Jamaludin, Ku Johari \& Amat, 2018).

The study found that there are a number of factors that influence the emotional and motivational development of the members such as the person can understand the emotion they are experiencing, visualize the emotion in the visual, understand the emotion and be motivated to change the attitude of the delinquent. The results of this study provide the implication that each member can still be guided and builded by his personality and possibly due to negative external factors making them vulnerable and unable to control themselves. The implication of each activity is that each member has a desire to be better. In addition, 
members can identify themselves and other friends. By looking at their weaknesses and strengths, they can think wether what they do is beneficial or not to themselves.

\section{Conclusions}

The results of this program show that psycho-educational programs through an art therapy approach have a positive impact on students involved in delinquency problems. It clearly demonstrates that a combination of psycho-educational group counseling and an art therapy approach can increase students' awareness of the discipline problems they are having. This program also motivated the students to build their personality those they faced now. In the age of teenagers, many problem would be come especially from their environment and socializing. Hopefully, with this program would be a turning point to change their behavior and their life as a whole.

\section{References}

Abdul Rahman S.N.H, Hussein, H., \& Muhammad, R. (2017). Pendekatan 'LEPAS' Menggunakan Teknik Kaedah Terapi Seni Untuk Meneroka Emosi Pelajar Berpencapaian Sederhana Di Institut Pendidikan Guru Kampus Darulaman

American Art Therapy Association (2015). What is art therapy? Download at October 10, 2019.

Tunggak, B., Ngadi, S., \& Abu Naim, H. (2015). Delinkuen Pelajar dan Cadangan Penyelesaiannya Menerusi Model Pembangunan Sahsiah Remaja/Pelajar Muslim Bersepadu, Jurnal Hadhari. Bangi: Penerbit UKM.

De La Rue, L., \& Espelage, D.L. (2014). Family and Abuse Characteristics of gang-involved, presure-to-join non gang-girls, Psychology of Violence.

Elfida, D. (2005). Hubungan Antara Kemampuan Mengontrol Diri Dan Kecenderungan Berperilaku Delinkuen Pada Remaja. Jurnal Psikologi. Vol 1, Nomor 2.

Fagan, A.A., \& Lindsey A.M. (2014). Gender Differences in The Effectiveness of Deliquency Prevention Programs: What Can Be Learned From Experimental Research? Criminal Justice and Behavior. 41(9), 1057-1078.

Jabatan Kebajikan Masyarakat (JKM) http://www.jkm.gov.my/

Jamaludin, L. Ku Johari, K.S. \& Amat, S. (2018). Kesan Modul Intervensi Kaunseling Berasakan Terapi Bermain Adlerian Terhadap Kesejahteraan Kanak-kanak Mangsa Pengabaian. Jurnal Pendidikan Malaysia SI 1(1)(2018): 31-38.

Juliana, D., \& Kundayis, L. (2015). Art Therapy Bagi Meneroka Tingkah Laku Efeminet, Jurnal Penyelidikan Kent, 15, 17,-32.

Hanafi, F. \& Ismail, M.Z. (2006). Penghayatan Nilai-nilai Murni Dalam Masyarakat Berbilang Kaum di Malaysia. Prosiding Seminar Kebangsaan Pengajian Umum, 23-30. Skudai: Fakulti Pengurusan \& Pembangunan Sumber Manusia, Universiti Teknologi Malaysia.

Hirschi, T. (1969). Causes of Delinquency. Berkeley, CA: University of California Press.

Ismail, R. (2000). Delikuensi di Kalangan Penghuni Institusi Pemulihan dalam Noruzeyati Che Mohd Nasir. 2016. Aspek-aspek Keluarga dan Penglibatan Remaja Perempuan dalam Tingkah Laku Delinkuensi. UUM.

Mohammad, A., \& Khairul, A. (2009) Modalitiseni: Satu Intervensi Kepada Penolakan Klien Dalam Proses Kaunseling. Buku Koleksi Kertas Kerja Seminar Penyelidikan IPGM KBL, 36-46.

Nasir, R., \& Omar, F. (2006). Kesejahteraan Manusia: Perspektif Psikologi. Bangi: Universiti Kebangsaan Malaysia.

Santrock, J.W. (2003). Adolescence Perkembangan Remaja. Edisi Keenam. Alih bahasa: Adelan, B.S \& Saragih S. Jakarta: Erlangga. 
Siti Noorasmah, H. (2016). Keberkesanan Terapi Seni Lukisan Terhadap Remaja Mangsa Penderaan Seksual. Universiti Malaysia Terengganu. Disertasi Sajana.

Sri Haryati. (2018). Pendekatan Kognitif Untuk Menurunkan Kecenderungan Perilaku Delinkuen Pada Remaja. Menara Ilmu.

Sweeney, T. J. (2009). Adlerian Counseling and Psychotherapy: A Practitioner's Approach. New York, NY: Taylor \& Francis.

Turgay, A. (2009). Psychopharmacological Treatment of Oppositional Defiant Disorder, Journal ADHD Toronto Clinic. University of Toronto, Ontario, Canada.

Zulkifli \& Azlinawati. (2006). Pendisiplinan Pelajar Melayu di Sekolah Menengah Berasrama: Kajian Terhadap Kaedah yang Dijalankan di Sekolah Menengah Kebangsaan Agama Terpilih di Utara Semenanjung. Institut Penyelidikan, Pembangunan dan Pengkimersilan. Shah Alam: Univeriti Teknologi Mara. 